\title{
СОЦІАЛЬНО-ІНФОРМАТИВНА НАСИЧЕНІСТЬ ЯК УМОВА ЕФЕКТИВНОЇ ОРГАНІЗАЦІЇ САМОСТІЙНОЇ НАВЧАЛЬНОЇ ДІЯЛЬНОСТІ МАЙБУТНІХ ПЕРЕКЛАДАЧІВ ТА ШЛЯХИ ЇЇ РЕАЛІЗАЦЇ̈
}

Остапенко С. А. Соціально-інформативна насиченість як умова ефективної організації самостійної навчальної діяльності майбутніх перекладачів та шляхи її реалізації.

У статті розглянуто поняття соціально-інформативної насиченості, іiї вплив на ефективну організацію самостійної навчальної діяльності студентів, генезу застосування новітніх та інформаційних технологій у навчальному процесі, надано характеристику основних форм та методів роботи в процесі підготовки майбутніх перекладачів.

Ключові слова: соціально-інформативна насиченість, самостійна навчальна діяльність, новітні технологій, професійна компетентність.

Остапенко С. А. Социально-информативная насыщенность как условие эффективной организации самостоятельной деятельности будущих переводчиков и пути её реализации.

В статье рассматривается понятие социально-информационной насыщенности, ее влияние на организацию самостоятельной учебной деятельности студентов, генезу использования информационных и современных технологий в учебном процессе, представлена характеристика основных форм и методов работы в процессе подготовки будущих переводчиков.

Ключевые слова: социально-информационная насыщенность, самостоятельная учебная деятельность, современные технологии, профессиональная компетентность.

Ostapenko S. A. Social and informative saturation as a condition for the effective organization of independent activities of future translators and ways to implement it.

The article deals with the notion of social-informational satiety, its influence on the students' selfdirected educational activity, evolution of modern and informational technologies application in educational process, describes forms and methods used in the process of future translators preparation

Key words: social-informational satiety, self-directed educational activity, modern technologies, professional competence.

Навчити студентів оволодівати знаннями самостійно - одне із завдань сучасної вищої школи. Тому в процесі опанування студентами навчальних дисциплін у вищому навчальному закладі освіти необхідно формувати самостійність мислення, сприяти прагненню відкривати нові знання і способи оволодіння ними. Формування професійної компетентності студента набуде результативності за підтримки його прагнення власними силами засвоїти знання, оволодіти оптимальними способами навчальної діяльності й застосувати їх на практиці, заохочення пізнавально-інтелектуальної активності. Такому заохоченню сприяє соціальноінформативна насиченість самостійної навчальної діяльності.

Український дидакт С. Гончаренко пише про те, що в нашому суспільстві нині відчутні кожному процеси, пов'язані зі збільшенням інформаційного потоку та використанням сучасних інформаційних технологій [1]. Аналіз наукових джерел показує, що терміни «інформаційне суспільство» та «інформатизація суспільства» останнім часом посідають чільне місце у педагогічних дослідженнях науковців США, Великої Британії, Канади, а також багатьох держав Європейського співтовариства. Масштабні зміни, пов'язані з виникненням і розповсюдженням мультимедійних, цифрових технологій охопили усі галузі життя, а тому повинні контролюватися та спрямовуватися відповідно до інтересів суспільства, зокрема, відповідно до інтересів освітніх систем. В інформаційному суспільстві змін зазнають власне функції знань, для забезпечення адекватності яких Х. Шпінер визначає дванадцять цілей:

- свобода знань, яка передбачає право на критику знань, право на розвиток i вдосконалення знань, право на захист інформації особистого характеру, право на розповсюдження відкритої інформації;

- незалежність у галузі роботи з інформацією;

- рівність можливостей у справі розвитку, збереження й поширення знань; 
- структурний плюралізм, що заперечує універсальні схеми і визнає право на функціонування різних структур, які відповідають природі конкретного знання;

- створення спеціальних «зон знань» для конкретних проблем, у рамках яких структуруватимуться нові знання та переглядатимуться старі;

- відповідальність за незаконне використання інформації, а також іiі застосування на шкоду суспільству, окремим фізичним особам;

- розвиток інфраструктури критики, необхідної для апробації нового знання, перегляду застарілих уявлень, положень, теорій;

- реальне інформаційне забезпечення потреб суспільства, тобто подання інформації, дійсно необхідної для розв'язання актуальних проблем конкретних користувачів;

- інформаційне самовизначення;

- функціональний розподіл праці в галузі знань, що передбачає виконання окремих функцій, пов'язаних із розвитком, поширенням, обробленням, збереженням і представленням інформації;

- децентралізована організація знань як засіб боротьби з монополізацією знань, що $\epsilon$ небезпечним в інформаційному суспільстві;

- стратегія гнучкого взаємодоповнювального використання технічних і нетехнічних рішень [4].

У першу чергу, інформативна насиченість характеризує галузь соціального розвитку й безпосередньо стосується освітньої галузі. Унаслідок цього нині певною мірою посилилося протистояння власне науково-технічного та гуманітарного типів культур, i соціальноінформативна насиченість дозволяє зняти чи достатньою мірою нівелювати це протистояння. Класична гуманітарна культура, у змісті якої формується професійний образ студентів філологічних спеціальностей покликана зберігати й розвивати духовні цінності, враховує технічну зумовленість соціальної галузі, той факт, що сучасна людина перетворилася на функціональний елемент техносфери. А. Сіцінський цілком справедливо зауважує, що в нашій країні інформатизація суспільства зумовила не лише до формування типів людей із різними рівнями володіння комп'ютерною технікою, а й 3 різним баченням місця комп'ютерних технологій у житті суспільства [3, с. 42].

Проблемі розроблення навчально-методичного і інформаційного забезпечення присвячено достатньо велику кількість досліджень і наукових публікацій (Я. Ваграменко, Е. Владимирська, А. Дорошкевич, А. Єршов, І. Ільясов, С. Машбіц, Н. Кузьміна, О. Прохоров, І. Роберт та інші). Однак, одностайної думки щодо структури, змістового наповнення з урахуванням специфіки навчальної дисципліни, специфіки використання технологій навчання, специфіки організації самостійної навчальної діяльності нині не сформовано.

Mema cmammi - на грунті аналізу сучасних інформативних та новітніх методів навчання визначити специфіку інформативної насиченості самостійної навчальної діяльності студентів, надати характеристику видам й формам роботи, що сприяють мотивацій самостійної навчальної діяльності в процесі підготовки перекладачів.

Моментальний доступ до різноманітної інформації, можливість іï активного використання, самостійне створення різноманітної продукції, упровадження комп'ютерних технологій у практичну освітню діяльність розширюють соціальні можливості тих, хто навчається Освітні системи насичуються інформаційною продукцією, у заклади освіти упроваджуються інформаційні засоби, що грунтуються на сучасних комп’ютерних досягненнях, використовуються новітні мультимедійні технології (мультимедіа від лат. multium - багато й media - засоби), засоби навчання, що містять у своїй структурі різні види інформації - у вигляді текстів, аудіо-, відео-, анімаційних елементів. За допомогою мультимедіа забезпечується інтерактивна дидактична взаємодія. Інформативна насиченість є водночас наслідком процесу інформатизації українського суспільства, застосування новітніх засобів вироблення, переробки, зберігання, розповсюдження інформації в найрізноманітніших їі аспектах. Варто говорити про інформативнонавчальну взаємодію викладача та студентів, що здійснюється засобами сучасних інформаційних технологій, залученням сучасної комп’ютерної техніки та можливостей internet.

Новітні можливості відкривають широкі перспективи для організації самостійної навчальної діяльності іншого, вищого гатунку: реальністю сьогодення стають консультації викладача та студентів on-line, унаочнення навчальної інформації завдяки заздалегідь підготовленим презентаціям, використання в навчальних цілях відео- та друкованої інформації мережі. 
3-поміж науковців-дослідників та медіа-педагогів, які розробляють цей напрям, можна назвати у першу чергу Ж. Жакіно, М. Ляховицького, П. Стефаненка, Ю. Усова. Цікаво, що практичні рекомендації М. Ляховицького стосуються саме інноваційно-технічної підготовки майбутніх філологів, викладачів іноземної мови: для формування тривалих знань і навичок 3 іноземної мови потрібна єдність трьох компонентів-образів, уважає науковець (слухового, артикуляційного й зорового), але слуховий компонент можна вважати домінуючим [4, с. 23].

Своєрідний дидактичний прорив у галузі використання аудіовізуальних технологій у процесі навчання здійснила французька дослідниця Ж. Жакіно (Genevieve Jacquinot) - авторка багатьох статей і книг з питань медіаосвіти. Класикою аудіовізуального навчання стала книга дослідниці «Image et pedagogie». Уже друге десятиліття цією роботою послуговуються науковці 3 метою дидактичного семіологічного аналізу навчальних, художніх фільмів, телевізійних навчальних передач. За рекомендаціями Ж. Жакіно, варто приділяти увагу не змісту (не лише змісту) конкретного фільму чи передачі, а формі, яка надається семантичній тканині аудіовізуального твору експресивними засобами, де дидактичні цілі перетинаються 3 формою художнього самовиразу.

Аналогічні судження висловлював у педагогічній публіцистиці ще у 80 -х роках минулого століття естонський педагог Ю. Усов, - один із «першопрохідців» медіаосвіти. Його твори («У світі екранних мистецтв», «Основи екранної культури» та інші) написані 3 майстерністю й публіцистичним талантом, поєднують глибину науково-педагогічного підходу й концептуальну впевненість у необхідності медіаосвіти на основі екранних мистецтв [5]. На відміну від багатьох інших науковців, які працювали і працюють у галузі медіаосвіти (Л. Гейхман, В. Кашкіна, М. Ляховицький, Х. Шпінер), які вважали, що головний натиск під час занять зі студентами треба робити на сучасні технічні засоби навчання, Ю. Усов наголошував, що головне - це розвиток художнього сприймання, творчого мислення й аудіовізуальної грамотності за допомогою творів аудіовізуальних мистецтв. Думка, яка видається надзвичайно слушною з точки зору фахової підготовки майбутніх філологів. У своєму визначенні аудіовізуальної грамотності Ю. Усов наблизився до концепцій західноєвропейських, зокрема, французьких педагогів, які наголошують на виробленні у студентів критичності, самостійності мислення, критичного ставлення до дійсності, розвитку всіх видів сприймання та медіа грамотності. Тривалий час в українських освітніх реаліях недооцінювалося, а нерідко й просто ігнорувалося поняття медіаосвіти як системи використання засобів масової комунікації 3 дидактичною метою (преси, телебачення, комп'ютерної техніки, фотографії), в останні роки завдяки працям Л. Волошиної, С. Жили та інших вітчизняних науковців розроблено методологічні засади використання аудіовізуальних мистецтв у вищій школі, створено авторські навчальні програми, моделі, що базуються на використанні сучасних мультимедіа, тож маємо достатне теоретичне підгрунтя для реалізації дидактичної умови соціальноінформативної насиченості самостійної навчальної діяльності студентів.

Задля формування професійної компетентності студентів перекладацьких спеціальностей варто організовувати самостійну навчальну діяльність у формі інтерактивного діалогу, способу взаємодії суб'єктів навчального процесу за допомогою комп'ютерної техніки та певних програм. На відміну від діалогу, що передбачає заздалегідь заплановані відповіді на текстові команди, «під час інтерактивного діалогу передбачаються можливості реалізації навчальної програми у більш вільній формі, тим самим забезпечується вибір варіантів відповідей, режиму роботи».

Консультації, індивідуальні інтерактивні співбесіди та опосередкований контроль за ходом здійснення індивідуальної самостійної роботи в інтерактивному режимі (франц. Regime, від лат. Regimen -керування) - режимі взаємодії користувача з комп'ютером, за якого кожен запит користувача викликає негайну відповідну дію, відповідь, обмін повідомленнями відбувається в реальному часі. Адже ще засновник програмованого навчання Б. Скіннер зауважував: навчання якісно покращується, якщо підкріплюється правильне реагування, через те, що підкріплення вибірково скеровує поведінку до заздалегідь висунутої мети, воно буде більш ефективним, аніж контроль чи покарання за допомогою негативної оцінки. Саме досліди Б. Скіннера, Р. Фрейджера, Д.Фрейдимена показали, що люди навчаються більш легко й ефективно, якщо в ході навчання їм забезпечується миттєвий і точний зв'язок з їх успіхами. I комунікація в такому випадку дійсно набуває особистісних, персоніфікованих рис. Основу дистанційного 
навчання складають такі правила: швидкість навчання зростає, якщо навчальний матеріал представлений у вигляді дискретних частин; студент повинен реагувати, матеріал запам'ятовується краще, якщо студент бере активну участь у навчальному процесі. Також додамо до цих правил, що соціально-інформативна насиченість навчального процесу й самостійної навчальної діяльності дозволяє забезпечити емоційне залучення студента до процесу засвоєння інформації, що створюється за рахунок оперативного активного реагування та позитивного підкріплення, а позитивні емоції, будучи «каталізатором» інтелектуальної активності особистості, здатні підвищити ефективність засвоєння навчального матеріалу як безпосередньо, так і на відстані. Дидактична умова соціально-інформативної насиченості дозволяє поєднати сучасний технічний інструментарій із суспільними та особистісними реаліями.

Дистанційна самостійна навчальна діяльність, що базується на використанні сучасних мультимедіа - відносно нова організаційна форма. Вона грунтується на інтеграції кращих традиційних методів навчання й нових інформаційно-комунікаційних технологій, принципах самостійного навчання. У межах цього різновиду самостійної навчальної діяльності апробуються нові методи та прийоми, процес самостійної навчальної діяльності може відбуватися будь-де й будь-коли, єдина умова - технічне забезпечення доступу до мережі internet. Серед таких новітніх методів дослідники виокремлюють:

- кейс-методи - сукупність методів самостійної дистанційної роботи, які засновуються на використанні наборів (кейсів) текстових, аудіовізуальних і мультимедійних навчальнометодичних матеріалів для самостійного вивчення студентами, під час організації та здійснення консультування;

- тьюторські методи - надання тематичної цілеспрямованої допомоги, патронаж самостійної навчальної діяльності студентів за допомогою сучасних комп'ютерних технологій;

- мережеві технології та похідні від них методи - базуються на оперативному використанні матеріалів освітніх сайтів, інструктивних і навчально-методичних матеріалів тощо.

Отже, самостійна навчальна діяльність сприяє формуванню у студентів інтелектуальних якостей, необхідних майбутньому спеціалістові. Інформативні ж насиченість в свою чергу сприяє розширенню соціальних можливостей тих, хто навчається, їх медіа грамотності, дозволяє забезпечити емоційне залучення студента до процесу засвоєння інформації, що створюється за рахунок оперативного активного реагування та позитивного підкріплення. Впровадження таких новітніх методів як мережеві технологій, тьоторські методи, кейс-методи, дистанційне навчання забезпечують здійснення самостійної навчальної діяльності студентів перекладацьких спеціальностей в інтерактивному режимі і тим самим мотивує цей вид діяльності.

\section{Література}

1. Гончаренко С. У. Український педагогічний словник / Семен Устинович Гончаренко. - К. : Либідь, 1997. - 374 с. 2. Ляховицкий М. В. Теория и практика применения технических средств в обучении иностранным языкам / М.В.Ляховицкий. - К. : Вища школа, $1989 .-255$ с. 3. Сіцінський А. До проблеми структурування професійних знань в інформаційному суспільстві / А. Сіцінський // Педагогіка і психологія професійної освіти. - 2003. - № 2. - С. 40-47. 4. Шпинер Х. Организация знания в информационном обществе / Х. Шпинер // Техника, общество и окружающая середа : материалы международной научной конференции. - М. : МГУ, 1998. - С. 52-54. 5. Усов Ю. Н. Методика использования киноискусства в идейно-эстетическом воспитании / Ю. Н. Усов. - Таллинн, 1980. - 112 с.

\section{ПРОФЕСІЙНА МОТИВАЦІЯ ТА ЇЇ РОЛЬ У ФОРМУВАННІ МОТИВАЦІЇ ДО ВИВЧЕННЯ ІНОЗЕМНИХ МОВ У СТУДЕНТІВ НЕМОВНИХ ВНЗ}

Побережна Н. О. Професійна мотивація та іiі роль у формуванні мотивації до вивчення іноземних мов у студентів немовних ВНЗ.

У статті аналізуються шляхи формування оптимальної мотивації учіння студентів немовних ВНЗ до оволодіння іноземною мовою у процесі навчання. Виявлено умови, що впливають на формування позитивної мотивації слухачів до оволодіння іншомовними здібностями.

Ключові слова: мотивація, мотивація учіння, професійна мотивація, іншомовні здібності. 